\title{
DOMINASI PERAN PEMERINTAH DALAM PERTUMBUHAN EKONOMI NASIONAL DI MASA COVID-19
}

(Government's Role Domination In National Economic Growth In The Time Of Covid 19)

\author{
Nuralia \\ Direktorat Jenderal Kekayaan Intelektual, \\ JL. H.R Rasuna Said Kav 8-9, Kuningan, Jakarta Selatan, 12940 \\ e-mail: nuralia@dgip.go.id \\ Nico Andrianto \\ Badan Pemeriksa Keuangan \\ JI. Jenderal Gatot Subroto No. 31, Jakarta Pusat, 10210 \\ e-mail: Nico.andrianto@bpk.go.id
}

\begin{abstract}
Abstrak
Dalam RPJMN 2015-2019, yang menekankan pada pembangunan infrastruktur dijelaskan bahwa pemerintah membuka peluang terjadinya kerjasama antara pemerintah dan swasta dalam berbagai proyek strategis dengan melibatkan sektor swasta sebagai pemilik modal dengan konsesi selama jangka waktu tertentu. Mekanisme ini semakin mapan dalam RPJMN berikutnya yang memberikan penekanan pada pembangunan SDM unggul dan berdaya saing. Pertanyaan yang mengemuka, sebesar apakah peran pemerintah. Tulisan ini berupaya memotret peran pemerintah dalam pembangunan perekonomian, khususnya saat terjadi pandemi Covid-19 dan pasca implementasi UU Cipta Kerja. Penulis menggambarkan sebesar apa peran pemerintah dalam proses pertumbuhan ekonomi dan upaya yang mendorong pemerataan, sebagai bagian dari sebuah proses pembangunan yang terencana. Analisis yang dihasilkan didukung dengan data statistik yang memberikan gambaran perekonomian nasional saat ini. Pemahaman atas seberapa besar peran pemerintah ini bisa menjadi bahan evaluasi ke depan mengenai bagaimana optimalisasi pembangunan ekonomi bisa dilakukan, dengan memahami aktor-aktornya yang berpengaruh dan peran penting yang bisa dilaksanakan.
\end{abstract}

Kata kunci: Pandemi, Cipta Kerja, Pemulihan Ekonomi

\begin{abstract}
In the 2015-2019 RPJMN which emphasizes infrastructure development, it is explained that the government opens opportunities for cooperation between the government and the private sector in various strategic projects by involving the private sector as the owner of capital with concessions for a certain period of time. This mechanism is more established in the next RPJMN which emphasizes the development of superior and competitive human resources. The question that arises is how big is the role of the government. This paper seeks to portray the role of the government in economic development, especially during the Covid-19 pandemic and after the implementation of the Job Creation Law. The author describes how much government hegemony in the process of economic growth and efforts to promote equity, as part of a planning development process. The resulting analysis is supported by statistical data that provides an overview of the current national economy. An understanding of how big the role of the government is can be used as material for future evaluations of how the optimization of economic development can be done, by understanding the influencing actors and the important roles that can be carried out.
\end{abstract}

Keywords: Pandemic, Job Creation, Economic Recover 


\section{A. Pendahuluan}

Pembangunan perekonomian menjadi bagian dari perencanaan pembangunan nasional pemerintah di banyak negara. Perekonomian adalah salah satu sektor yang perlu didorong untuk mencapai target-target pertumbuhan maupun pemerataan. Tak terkecuali, Indonesia juga memasukkan pembangunan ekonomi dalam RPJMN 2015-2019. Sebagai program pemerintah yang utama muncul pertanyaan terkait pembangunan perekonomian.

Dalam era globalisasi, di mana modal, tenaga kerja, dan keahlian bisa mengalir menuju negara manapun, peran swasta memiliki peran yang semakin besar dalam mendorong perekonomian. Dengan investasi langsung, maka pertumbuhan ekonomi bisa dipicu oleh perusahaan-perusahaan yang berinvestasi di berbagai bidang dan sektor perekonomian. Peran swasta semakin memiliki porsi yang besar dalam mendorong pertumbuhan perekonomian, di sektor perkebunan, pertambangan, pariwisata, perdagangan, transportasi, atau bahkan pendidikan dan kesehatan.

Dalam RPJMN 2015-2019 yang menekankan pada pembangunan infrastruktur dijelaskan bahwa pemerintah membuka peluang terjadinya Kerjasama antara pemerintah dan swasta (KPBU) dalam berbagai proyek strategis. Pembangunan Jalan Tol, Jembatan, Pengoperasian KEK, ataupun kereta cepat melibatkan sektor swasta sebagai pemilik modal dengan konsesi selama jangka waktu tertentu. Mekanisme ini tentu semakin mapan dalam RPJMN berikutnya yang memberikan penekanan pada pembangunan SDM unggul dan berdaya saing.

Dengan munculnya pandemi Covid-19 kembali menerbitkan pertanyaan, bagaimana hegemoni peran pemerintah dalam pembangunan ekonomi nasional. Adanya pandemi Covid-19 menimbulkan dampak yang memukul sektor swasta sedemikian rupa sehingga banyak aktifitas usaha yang merugi, karena adanya Pembatasan Sosial Berskala Besar (PSBB) dan melemahnya aktifitas perekonomian. Dampaknya terhadap perekenomian adalah banyaknya Pemutusan Hubungan Kerja (PHK), dan kontraksi perekonomian yang mendorong perekonomian memasukidepresimulaiSemester II Tahun 2020. Kondisi khusus ini membantu proses pengamatan peran pemerintah dalam pembangunan ekonomi, di mana terjadi peningkatan signifikan peran pemerintah melalui berbagai program pemberian jaring pengaman sosial untuk PSBB, subsidi upah, stimulus perekonomian, dan program-program yang mendorong UMKM untuk bertahan dalam kondisi pandemi.

Tulisan ini berupaya memotret peran pemerintah dalam pembangunan perekonomian di Indonesia dalam beberapa tahun terakhir, khususnya saat terjadi pandemi Covid-19. Tulisan ini berupaya menggambarkan sebesar apa dominasi pemerintah dalam proses pertumbuhan ekonomi dan upaya-upaya yang mendorong pemerataan, sebagai bagian dari sebuah proses pembangunan yang terencana. Analisis yang dihasilkan didukung dengan datadata statistik yang memberikan gambaran perekonomian nasional saat ini. Pemahaman atas seberapa besar peran pemerintah ini bisa menjadi bahan evaluasi ke depan mengenai bagaimana optimalisasi pembangunan ekonomi bisa dilakukan, dengan memahami aktoraktornya yang berpengaruh dan peran-peran penting yang bisa mereka lakukan. 


\section{B. Metode Penelitian}

Dalam melakukan penelitian ini, digunakan analisis hukum normatif dengan pendekatan peraturan perundang-undangan dan konseptual. Metode pengumpulan data yang dilakukan adalah dengan Penelitian Kepustakaan (Library Research) dengan melakukan analisis data kualitatif. Dalam penelitian ini, penelitian kepustakaan bertujuan untuk menghimpun data-data yang berasal dari buku-buku, peraturan perundang-undangan, jurnal ilmiah yang berhubungan dengan permasalahan penelitian yang diteliti. Alat pengumpulan data yang dipergunakan dalam penelitian ini adalah dengan menggunakan studi dokumen, yaitu dengan mempelajari serta menganalisa bahan pustaka (data sekunder). ${ }^{1}$

\section{Pembahasan}

Omnibus Law adalah undang-undang yang menitik beratkan pada penyederhanaan jumlah regulasi. Omnibus Law juga dapat diartikan suatu konsep produk hukum yang berfungsi untuk mengkonsolidir berbagai tema, materi, subjek, dan peraturan perundang-undangan pada setiap sektor yang berbeda untuk menjadi produk hukum besar dan holistik. Omnibus Law adalah langkah menerbitkan satu UU yang bisa memperbaiki sekian banyak UU yang selama ini dianggap tumpang tindih dan menghambat proses kemudahan berusaha. $^{2}$

Pandemi Covid-19 menimbulkan berbagai dampak negatif yang signifikan hingga mengakibatkan krisis kesehatan dan ekonomi yang terburuk di dunia sejak Great Depression 1930. Aktivitas ekonomi terhenti dengan diberlakukannya pembatasan aktivitas masyarakat, sehingga jutaan orang kehilangan pekerjaan dan meningkatkan kemiskinan. Pada kondisi seperti ini, stimulus fiskal sangat diperlukan untuk mengatasi permasalahan kesehatan, mencegah kenaikan pengangguran, serta membantu sektor usaha dan UMKM. Namun, penurunan penerimaan pemerintah menyebabkan ruang fiskal menjadi terbatas. Koordinasi antar otoritas sangat diperlukan untuk mengatasi dampak pandemi. Dalam konteks ini, bank sentral, baik di negara maju maupun berkembang turut membantu pemerintah mengatasi keterbatasan ruang fiskal melalui kebijakan non-konvensional pembelian surat berharga pemerintah.

Pemerintah melalui Undang-Undang Cipta Kerja mempermudah investasi dan pemulihan perekonomian nasional terlihat pada pengembangan sektor UMKM dan Koperasi. Regulasi ini juga menawarkan berbagai macam kemudahan berusaha dan perlindungan bagi UMKM. Selain itu, penyesuaian berbagai aspek pengaturan yang berkaitan dengan peningkatan ekosistem investasi, kemudahan dan percepatan proyek strategis nasional.

\section{Dampak Covid-19 Terhadap Perekonomian}

Sejak pertengahan Februari 2020, pandemi Covid-19 terus menyebar ke luar Tiongkok dan menambah jumlah korban terinfeksi ataupun yang meninggal dunia. Beberapa negara Emerging Markets (EM) seperti India dan Brazil mengalami lonjakan kasus infeksi Covid-19. Sementara itu, beberapa negara Advanced Economies (AE) seperti Amerika Serikat (AS) dan Euro Area (EA) (terutama Spanyol dan Prancis)

1 Cresswell, Jhon W. Research Design Pendekatan Kualitatif, Kuantitatif, dan Mixed Edisi Ketiga

2 Antoni Putra, “Penerapan Omnibus Law Dalam Upaya Reformasi Regulasi” Jurnal Legislasi Indonesia, (2020):222. 
terindikasi menuju second wave, setelah sempat melandai pada Mei dan Juni 2020. Hingga 16 September 2020, total kasus infeksi terbesar didominasi oleh AS (6,7 juta kasus), India (5 juta kasus), Brazil (4,3 juta kasus), dan Rusia (1 juta kasus). ${ }^{3}$

Penerapan containment measures di berbagai negara untuk menekan penambahan kasus Covid-19 berdampak pada perlambatan ekonomi global. Pada awal penyebaran, berbagai negara menerapkan kebijakan containment berupa pembatasan perjalanan (travel restriction), social distancing, hingga lockdown. Lockdown yang ketat menyebabkan investasi global tertunda, disrupsi pada supply barang, dan tingkat pengangguran meningkat. Di sisi konsumsi, ketidakpastian yang meningkat akibat pandemi menyebabkan konsumen lebih selektif dan menahan belanja sehingga permintaan konsumsi global melemah tajam.

Covid-19 juga berdampak pada penurunan kinerja ekspor dan sektor pariwisata global. Pelemahan permintaan global mengakibatkan pemburukan kinerja ekspor barang global yang turun sebesar -2,8 persen qtq pada TW1-20, dan makin dalam hingga -15 persen qtq pada TW220. Di sektor pariwisata, pembatasan perjalanan yang meluas dan level of social distancing menyebabkan kinerja industri pariwisata turun signifikan. Berdasarkan skenario United Nation World Trade Organization (UNWTO), international tourist arrivals berpotensi turun 60 persen hingga 80 persen pada 2020 dibandingkan 2019 seperti ditunjukkan oleh gambar 1. ${ }^{4}$ Penurunan ekspor dan wisatawan internasional berdampak pada pelemahan penerimaan fiskal, terutama pada negaranegara yang memiliki ketergantungan tinggi pada perdagangan dan pariwisata.

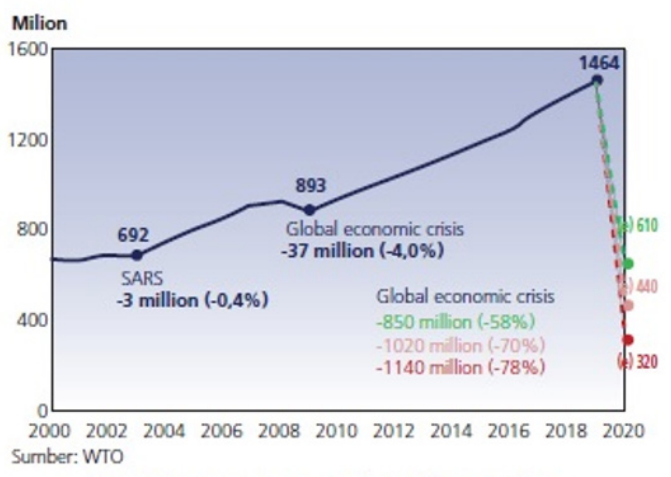

\section{Gambar 1 Grafik International Tourist Arrival During Covid-19}

Covid-19 menyebabkan pengeluaran pemerintah meningkat tajam untuk membantu sektor kesehatan, bisnis, dan rumah tangga, sehingga memperlebar defisit fiskal. Berbagai fiscal measures yang ditempuh pemerintah di antaranya berupa pendanaan kebutuhan darurat sektor kesehatan, tunjangan gaji, pembayaran cuti, pemberian pinjaman dan hibah kepada perusahaan. IMF memperkirakan defisit anggaran pemerintah secara global akan melebar hingga lebih dari -6 persen PDB pada 2020 (dari -3,7 persen PDB pada 2019) seperti ditunjukkan oleh gambar 2. Amerika Serikat (AS) menjadi kontributor utama pelebaran defisit fiskal global, seiring berbagai stimulus fiskal yang masif. ${ }^{5}$

3 Adrian, T., \& Natalucci, F., “COVID-19 Worsens Pre-existing Financial Vulnerabilities”. https://blogs.imf.org/2020/05/22/covid-19-worsens-pre-existing-financial-vulnerabilities/

4 Adrian, T., \& Natalucci, F., “COVID-19 Worsens Pre-existing Financial Vulnerabilities”. https://blogs.imf.org/2020/05/22/covid-19-worsens-pre-existing-financial-vulnerabilities/

5 International Monetary Fund (IMF) https://www.imf.org/en/Home (diakses 20 Februari 2021 


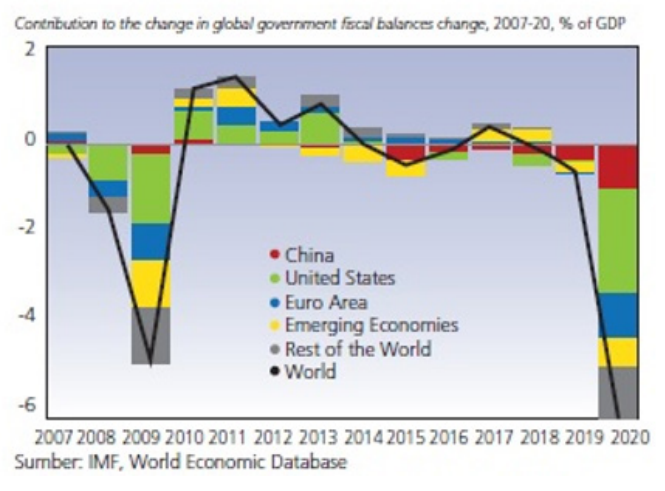

Gambar 2 Grafik Government Fiscal Balances Changes

Kenaikan pengeluaran pemerintah ditengah penurunan penerimaan juga menyebabkan kenaikan tingkat utang. Rasio utang sektor publik diprediksi melampaui catatan historis utang selama 150 tahun terakhir, termasuk saat perang dunia I dan II. Rasio utang publik pada 2020 diestimasi dapat mencapai 122 persen PDB di AE, dan 62 persen PDB di EM. Kenaikan debt ratio tertinggi akibat pandemi diperkirakan dialami oleh AS seiring defisit yang melebar untuk membiayai berbagai benefit antara lain unemployment benefits, payroll tax deferral, dan subsidi gaji kepada perusahaan kecil dan menengah, yang dapat dilihat pada gambar 3 dan $4 .{ }^{6}$

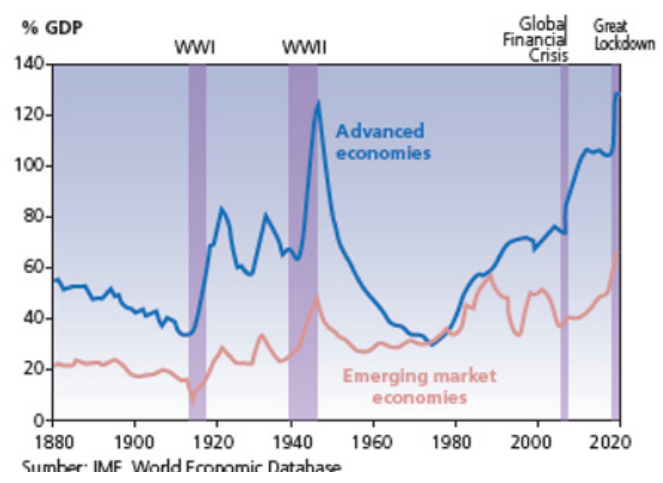

Gambar 3 Grafik Global Public Debt

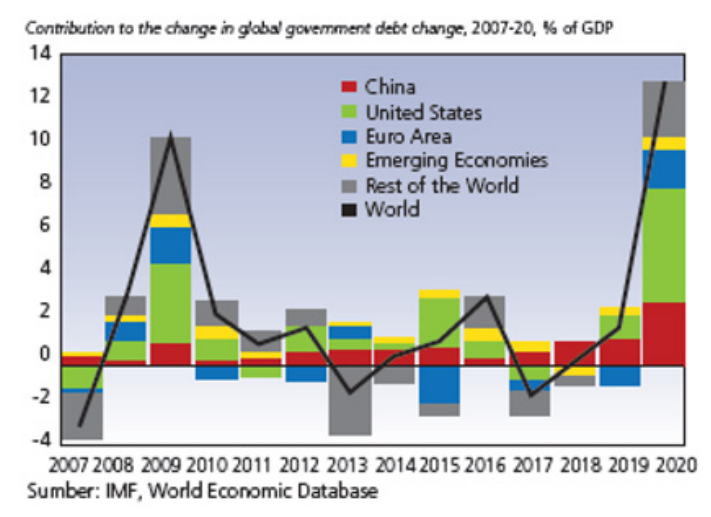

Gambar 4 Grafik Global Government Debt Changes

\section{Kebijakan Bank Indonesia}

Sepanjang Februari-September 2020, Bank Indonesia (BI) telah menempuh bauran kebijakan dalam rangka memitigasi risiko Covid-19 terhadap perekonomian dan mendorong program Pemulihan Ekonomi Nasional (PEN). $\mathrm{BI}$ memperkuat seluruh instrumen bauran kebijakan yang dimiliki untuk menjaga stabilitas nilai tukar Rupiah, mengendalikan inflasi, dan mendukung stabilitas sistem keuangan. Bahkan, BI mengambil langkah kebijakan lanjutan secara terkoordinasi dengan pemerintah dan Komite Stabilitas Sistem Keuangan untuk menjaga stabilitas makro ekonomi dan sistem keuangan, serta pemulihan ekonomi nasional.

Kebijakan akomodatif BI ditempuh melalui pemotongan suku bunga. Sejak awal 2020, BI telah menurunkan BI-7 Day Reverse Repo Rate (BI7DRR) sebesar 100bps menjadi 4,00 persen. Penurunan dilakukan pada Februari, Maret, Juni, dan Juli 2020 masing-masing sebesar 25bps. Keputusan ini konsisten dengan prakiraan inflasi yang tetap rendah, stabilitas eksternal

6 Arquie, A., et.al., "COVID-19: Has the Time Come for Mainstream Macroeconomics to Rehabilitate Money Printing?", Policy Brief CEPII No.31

http://www.cepii.fr/cepii/fr/publications/pb.asp (diakses 20 Februari 2021) 
yang terjaga, dan sebagai langkah lanjutan untuk mendorong pemulihan ekonomi di masa pandemi Covid-19.

$\mathrm{BI}$ juga melanjutkan kebijakan stabilisasi nilai tukar Rupiah sesuai nilai fundamental dan mekanisme pasar di tengah masih berlanjutnya ketidakpastian pasar keuangan global. BI melakukan stabilisasi dan penguatan Rupiah melalui peningkatan intensitas kebijakan triple intervention di pasar spot, Domestic NonDeliverable Forward (DNDF), maupun pembelian SBN dari pasar sekunder. BI juga melakukan penurunan GWM valas dan memperluas jenis underlying transaksi bagi investor asing untuk memberikan alternatif lindung nilai atas kepemilikan Rupiah. Kebijakan stabilisasi nilai tukar juga didukung upaya untuk memperkuat ketahanan eksternal melalui kerja sama bilateral swap dan repo line dengan sejumlah bank sentral negara lain.

BI menempuh berbagai langkah kebijakan untuk menjaga ketersediaan likuiditas bagi pembiayaan kredit perbankan dan mempercepat upaya pemulihan ekonomi nasional. Upaya tersebut dilakukan melalui pembelian obligasi pemerintah, penyediaan likuiditas perbankan dengan repo SBN, swap valas, serta penurunan Giro Wajib Minimum (GWM) Rupiah. Selanjutnya, BI memperkuat sinergi ekspansi moneter dengan akselerasi stimulus fiskal pemerintah. BI membantu pendanaan APBN 2020 melalui pembelian SBN dari pasar perdana. Terdapat kebijakan makroprudensial, BI menempuh kebijakan akomodatif sejalan dengan bauran kebijakan nasional, termasuk berbagai upaya untuk memitigasi risiko di sektor keuangan akibat pandemi Covid-19.
Relaksasi kebijakan di antaranya berupa perpanjangan pelonggaran GWM Rupiah sebesar 50 bps bagi bank yang menyalurkan kredit UMKM dan ekspor impor, serta kredit nonUMKM sektor-sektor prioritas yang ditetapkan dalam program PEN dari 31 Desember 2020 menjadi sampai dengan 30 Juni 2021. BI juga menurunkan batasan down payment dari kisaran 5 persen - 10 persen menjadi 0 persen dalam pemberian kredit/pembiayaan kendaran bermotor untuk pembelian kendaraan bermotor berwawasan lingkungan, dengan tetap memerhatikan prinsip kehati-hatian.

\section{Kebijakan Pemerintah dalam Program PEN Untuk Dukung Korporasi}

Sesuai dengan Peraturan Pemerintah Nomor 43 Tahun 2019 dan/atau padat karya sesuai Peraturan Menteri Keuangan (PMK) 16/2020, fasilitas penjaminan kredit modal kerja korporasi ditujukan kepada pelaku usaha korporasi yang memiliki usaha berorientasi ekspor dan/atau padat karya yang memiliki minimal 300 karyawan. Pelaku usaha korporasi yang dijamin tidak termasuk kategori BUMN dan UMKM, dan tidak termasuk dalam daftar kasus hukum dan/atau tuntutan kepailitan serta memiliki performing loan lancar sebelum terjadinya pandemi Covid-19. Besaran tambahan kredit modal kerja yang dijamin bernilai antara Rp 10 Miliar sampai dengan Rp1 Triliun. Dalam skema penjaminan kredit modal kerja korporasi, porsi penjaminan sebesar 60 persen dari kredit, namun untuk sektor-sektor prioritas porsi yang dijamin sampai dengan 80 persen dari kredit. Sektor prioritas tersebut seperti pariwisata (hotel dan restoran), otomotif, TPT dan alas kaki, elektronik, kayu olahan dan sektor usaha lainnya 
yang memenuhi kriteria terdampak Covid-19.

Pemerintah menanggung pembayaran imbal jasa penjaminan sebesar 100 persen atas kredit modal kerja sampai dengan Rp300 Miliar dan 50 persen untuk pinjaman dengan plafon Rp300 Miliar sampai Rp 1 Triliun. Skema penjaminan direncanakan berlangsung hingga akhir 2021 dan diharapkan dapat menjamin total kredit modal kerja yang disalurkan perbankan hingga Rp100 Triliun.

Lembaga Pembiayaan Ekspor Indonesia (LPEI) dan PT. Penjaminan Infrastruktur Indonesia (PII) akan berkontribusi dalam skema penjaminan atas pinjaman modal kerja yang diberikan perbankan kepada pelaku usaha Korporasi padat karya. Kapasitas LPEI dan PT PII merupakan lembaga penjamin yang memiliki jenis penjaminan sovereign guarantee dan didukung peningkatan kapasitas finansial melalui Penyertaan Modal Negara (PMN).

Pemerintah juga akan menanggung Imbal Jasa Penjaminan (IJP) yang disediakan dalam bentuk subsidi, sehingga tidak membebani pelaku usaha. Dukungan yang diberikan pemerintah dalam skema penjaminan ini yaitu subsidi belanja IJP, PMN untuk LPEI dan PT PII, dan stop loss yang diberikan kepada penjamin untuk memastikan risiko yang ditanggung sesuai dengan porsi risiko gagal bayar dari pinjaman yang ditentukan. Stop loss diberikan dalam bentuk IJP stop loss yang ditanggung oleh Pemerintah, serta Pemerintah memberikan backstop apabila klaim melebihi threshold klaim yang ditanggung oleh PT PII.

Dalam rangka mendukung penyaluran kredit perbankan, Pemerintah juga melakukan penempatan dana pada bank umum mitra, antara lain Bank Himbara, Bank Pembangunan Daerah, serta Bank umum lainnya yang memenuhi kriteria yang disyaratkan. Penempatan dana pada bank umum disyaratkan untuk dilakukan leverage, sehingga penyaluran kredit diharapkan dalam jumlah yang berlipat dari penempaan dana. Sebanyak lima belas perbankan yang akan memanfaatkan fasilitas penjaminan pemerintah seperti Bank Central Asia, Bank Danamon Indonesia, Bank DBS Indonesia, Bank HSBC Indonesia, Bank ICBC Indonesia, Bank Maybank Indonesia, Bank Resona Perdania, Standard Chartered Bank, Bank UOB Indonesia, Bank Mandiri (Persero), Bank Negara Indonesia (Persero), Bank Rakyat Indonesia (Persero), Bank Tabungan Negara (Persero), Bank DKI, dan Bank MUFG.

Dukungan Insentif Listrik Untuk Industri, Bisnis dan Sosial dalam rangka meringankan beban listrik, serta untuk mendukung proses pemulihan ekonomi nasional, Pemerintah akan memberikan insentif listrik yang ditujukan untuk meringankan beban listrik bagi pelanggan Industri, Bisnis dan Sosial.

Pemberian insentif listrik berupa Relaksasi Tarif Minimum, untuk Industri, Bisnis dan Sosial melalui relaksasi penerapan aturan rekening minimum (RM), yaitu Pelanggan hanya membayar sejumlah jam pemakaian, dan selisihnya akan dibayarkan oleh Pemerintah. Target penerima yaitu pelanggan yang pemakaian kWh nya di bawah Energi Minimum 40 jam (Emin), dan direncanakan akan diberikan selama 6 bulan (Juli - Desember 2020).

Anggaran yang dibutuhkan sebesar $\mathrm{Rp} 3$ Triliun, yang direncanakan akan diberikan sebanyak 112.223 Pelanggan Sosial, dengan kebutuhan Rp285,9 Miliar; sebanyak 330.653 Pelanggan Bisnis mulai dari daya 900 VA ke atas, 
dengan kebutuhan Rp1.306,1 Miliar; sebanyak 28.886 Pelanggan Industri mulai dari daya 900 VA ke atas, dengan kebutuhan Rp1.408,9 Miliar; dan Pelanggan dengan golongan daya di bawah 900 VA (relaksasi biaya abonemen) dengan kebutuhan \pm Rp70 Miliar.

\section{Konsep Omnibus Law}

Konsep Omnibus Law ini digunakan oleh beberapa negara dengan sistem hukum Anglo Saxon Common Law seperti Amerika, Kanada, Irlandia, dan Suriname perundang-undangannya menggunakan pendekatan Omnibus Law atau Omnibus Bill. Konsep Omnibus Law memiliki karakteristik mampu mengubah dan menghapus beberapa regulasi menjadi satu peraturan yang mampu mencakup seluruh aspek. Proses pembentukan yang singkat mampu mengganti puluhan undang-undang menjadi satu regulasi yang sejalan. Sejauh ini tidak diatur secara jelas didalam Undang-Undang nomor 12 tahun 2011 tentang pembentukan perundang-undangan. Seharusnya regulasi konsep pembentukan undang-undang tersebut diatur lebih dulu agar pesan baik yang terdapat pada konsep tersebut mampu dilaksanakan dengan baik sehingga tidak menimbulkan permasalahan baru di masyarakat $^{7}$

\section{Penutup}

Berdasarkan uraian dan hasil analisis, maka penulis dapat menarik kesimpulan dan saran bahwa peran Pemerintah sangat dominan dalam pembangunan ekonomi, terutama dalam kondisi pandemi Covid-19. Dihadapkan pada kondisi terpukulnya sektor swasta sebagai dampak pandemi, pemerintah mengambil banyak kebijakan di bidang ekonomi yang bertujuan untuk memulihkan perekonomian. Besarnya peran pemerintah yang bisa dikatakan sebagai sebuah dominasi tersebut adalah dalam upaya memulihkan perekonomian yang ditunjukkan oleh uraian adalah Pandemi Covid-19 berdampak luas pada ekonomi di berbagai sektor. Koordinasi yang erat antara fiskal dan moneter sangat diperlukan untuk menerapkan strategi dan bauran kebijakan yang tepat. Bank sentral, baik di Advanced Economies ( $\mathrm{AE}$ ) maupun di Emerging Market (EM), mengambil peran cukup besar di tengah ruang fiskal yang terbatas, di antaranya melalui kebijakan non-konvensional berupa pembelian surat-surat berharga pemerintah. Di Indonesia, $\mathrm{BI}$ berperan dalam membantu pemerintah melalui pembelian Surat Utang Negara (SUN) dan/atau Surat Berharga Syariah Negara (SBSN) berjangka panjang di pasar perdana.

Bank Indonesia juga bersinergi dengan pemerintah dalam rangka memenuhi kebutuhan pembiayaan penanganan Covid-19 melalui kesepakatan bersama antara pemerintah dan $\mathrm{BI}$ dalam skema burden sharing. BI membiayai public goods yang menyangkut hajat hidup orang banyak pada 2020. Kebijakan akan dilakukan secara prudent, dengan menerapkan tata kelola yang baik (good governance) dan transparan. ${ }^{8}$ Kebijakan tersebut, diharapkan dapat membantu percepatan pemulihan ekonomi nasional di tengah pandemi yang masih berlangsung. Ke depan, BI akan terus berkoordinasi dengan pemerintah, Otoritas Jasa Keuangan (OJK), dan otoritas terkait, serta senantiasa memantau perkembangan pandemi Covid-19 dalam

7 Matompo Osgar et al., "Konsep Omnibus Law Dan Permasalahan RUU Cipta Kerja" (2020)

8 Nugroho, Riant, Public Policy: Dinamika Kebijakan Publik, Analisis Kebijakan Publik, Manajemen Politik Kebijakan Publik, Etika Kebijakan Publik (Jakarta: Elex Media Komputindo, 2018) 
menetapkan langkah kebijakan yang diperlukan untuk memitigasi dan mengurangi dampaknya terhadap perekonomian nasional.

Penjaminan Pemerintah kepada Korporasi Padat Karya dilakukan melalui penyediaan fasilitas penjaminan, sehingga perbankan dapat menambah exposure kredit modal kerja kepada pelaku usaha. Program ini bertujuan untuk menunjang kebutuhan korporasi padat karya atas tambahan kredit modal kerja agar dapat kembali melakukan aktivitas secara maksimal selama masa pandemi. Diharapkan melalui program ini, pelaku usaha dapat menghindari aksi pengurangan tenaga kerja. Sesuai dengan Peraturan Pemerintah Nomor 43 Tahun 2019 dan/atau padat karya sesuai Peraturan Menteri Keuangan (PMK) 16/2020, fasilitas penjaminan kredit modal kerja korporasi ditujukan kepada pelaku usaha korporasi yang memiliki usaha berorientasi ekspor dan/atau padat karya yang memiliki minimal 300 karyawan. Pelaku usaha korporasi yang dijamin tidak termasuk kategori BUMN dan UMKM, dan tidak termasuk dalam daftar kasus hukum dan/atau tuntutan kepailitan serta memiliki performing loan lancar sebelum terjadinya pandemi Covid-19. Besaran tambahan kredit modal kerja yang dijamin bernilai antara Rp 10 miliar sampai dengan Rp1 triliun.

Pemerintah melalui implementasi UndangUndang Cipta Kerja memberikan banyak kemudahan berinvestasi serta meningkatkan kemudahan berusaha di Indonesia. Sebab, UU Cipta kerja sendiri dibuat untuk penyederhanaan, sinkronisasi, dan pemangkasan regulasi karena banyaknya aturan dan regulasi yang tumpang tindih serta menghambat penciptaan lapangan

9 Sarif Noman, "Dampak Komite Penanganan Covid-19 Dan Pemulihan Ekonomi Nasional Terhadap Berbagai Regulasi" (2021) kerja baik di pusat maupun di daerah. ${ }^{9}$

Saran dari penulis adalah Pemerintah melalui implementasi UU Cipta Kerja maka akan jelas terlihat dengan memberikan kemudahan, perlindungan dan pemberdayaan terhadap koperasi dan UMKM serta industri dan perdagangan nasional. Melalui Undang - Undang Cipta Kerja yang diharapkan bisa menjamin setiap warga Negara memperoleh pekerjaan serta mendapat imbalan dan perlakuan yang adil dan layak dalam hubungan kerja. Dominasi Peran Pemerintah dalam pemulihan perekonomian nasional terlihat pada pengembangan sektor UMKM dan Koperasi. Regulasi ini juga menawarkan berbagai macam kemudahan berusaha dan perlindungan bagi UMKM. Selain itu, penyesuaian berbagai aspek pengaturan yang berkaitan dengan peningkatan ekosistem investasi, kemudahan dan percepatan proyek strategis nasional yang berorientasi pada kepentingan nasional yang berlandaskan pada ilmu pengetahuan dan teknologi nasional. 


\section{DAFTAR PUSTAKA}

\section{A. Buku}

Cresswell, Jhon W. Research Design Pendekatan Kualitatif, Kuantitatif, dan Mixed Edisi Ketiga.

(Yogyakarta: Pustaka Pelajar, 2010)

Hettne, Bjorne, Teori Pembangunan dan Tiga Dunia (Jakarta: Gramedia Pustaka Utama: 2018)

Nugroho, Riant, Metode Penelitian Kebijakan (Yogyakarta: Pustaka Pelajar, 2018)

Nugroho, Riant, Public Policy: Dinamika Kebijakan Publik, Analisis Kebijakan Publik, Manajemen

Politik Kebijakan Publik, Etika Kebijakan Publik (Jakarta: Elex Media Komputindo, 2018)

Sibuea, Hotma P, Ilmu Politik Hukum (Jakarta: Erlangga, 2017)

Solichin, Abdul Wahab, Analisis Kebijakan: Dari Formulasi ke Penyusunan Model -Model Implementasi Kebijakan Publik (Jakarta : Sinar Grafika Offset, 2017)

Yustika, Ahmad Erani, Ekonomi Kelembagaan: Paradigma, Teori dan Kebijakan (Jakarta: Erlangga, 2018)

Wahyuni, Sari, Qualitative Research Method : Theory and Practice $3^{\text {rd }}$ Edition (Jakarta: Salemba Empat, 2019)

\section{B. Makalah/Artikel/Prosiding/Hasil Penelitian}

Antoni P, "Penerapan Omnibus Law Dalam Upaya Reformasi Regulasi” Jurnal Legislasi Indonesia, Vol 17 No 1 (2020)

Marlinah Lili, "Memanfaatkan Insentif Pajak UMKM Dalam Upaya Mendorong Pemulihan Ekonomi Nasional" Jurnal IKRA-ITH Ekonomika Vol.4 No.2 (2021)

Matompo Osgar et al., "Konsep Omnibus Law Dan Permasalahan RUU Cipta Kerja” Vol. 5 No. 1 (2020)

Sarif Noman, "Dampak Komite Penanganan Covid-19 Dan Pemulihan Ekonomi Nasional Terhadap Berbagai Regulasi" (2021)

\section{Internet}

Adrian, T., \& Natalucci, F.,"COVID-19 Worsens Pre-existing Financial Vulnerabilities”. https://blogs.imf.org/2020/05/22/covid-19-worsens-pre-existing-financial-vulnerabilities/ (diakses 20 Februari 2021)

Arquie, A., et.al., "COVID-19: Has the Time Come for Mainstream Macroeconomics to Rehabilitate Money Printing?", Policy Brief CEPII No. 31 http://www.cepii.fr/cepii/fr/publications/pb.asp (diakses 20 Februari 2021)

European Central Bank, "Monetary Policy Decision". https://www.ecb.europa.eu/pub/pdf/ scpwps/ecbwp657.pdf (diakses 25 Februari 2021)

International Monetary Fund (IMF) https://www.imf.org/en/Home (diakses 20 Februari 2021) Produk Domestik Indonesia Triwulan 2016 - 2020, Badan Pusat Statistik https://www.bps.go.id/publication/2020/10/16/54be7f82b7d3aa22f5e2c144/pdbindonesia-triwulanan-2016-2020.html (diakses 1 Maret 2021) 
RPJMN 2020 - 2024 https://www.bappenas.go.id/id/berita-dan-siaran-pers/rencana-pembangunan-jangka-menengah-nasional-rpjmn-2020-2024/ (diakses 1 Maret 2021)

Statistika Indonesia 2020, Badan Pusat Statistik https://www.bps.go.id/publication/2020/04/29/ e9011b3155d45d70823c141f/staststik-indonesia-2020.html (diakses 28 Februari 2021)

World Trade Organization (WTO) https://www.wto.org/english/tratop_e/covid19_e/covid19_e. htm (diakses 25 Februari 2021)

\section{Peraturan Perundang-Undangan}

Undang-Undang Dasar Negara Republik Indonesia Tahun 1945

Undang-Undang Nomor 11 Tahun 2020 Tentang Cipta Kerja

Peraturan Pemerintah No 43 Tahun 2019 Tentang Kebijakan Dasar Pembayaran Ekspor Nasional

Peraturan Pemerintah No 43 Tahun 2020 Tentang Perubahan Atas Peraturan Pemerintah Nomor 23 Tahun 2020 Tentang Pelaksanaan Program Pemulihan Ekonomi Nasional Dalam Rangka Mendukung Kebijakan Keuangan Negara Untuk Penanganan Pandemi 


\section{BIODATA PENULIS}

Nuralia, S.Kom., M.Kom., CITPE lahir di Palembang adalah Analis Sistem Aplikasi dan Jaringan Komputer di Direktorat Jenderal Kekayaan Intelektual, Kementerian Hukum dan Hak Asasi Manusia Republik Indonesia. Diploma 3 (D3) diselesaikan di Politeknik Negeri Sriwijaya tahun 2006, Strata satu (S1) Teknik Informatika di selesaikan di Universitas Esa Unggul tahun 2014, strata dua (S2) Universitas Budi Luhur tahun 2017, saat ini sedang menempuh Program Doktor Terapan Ilmu Administrasi Pembangunan Negara, Sekolah Tinggi Ilmu Administrasi, Lembaga Administrasi Negara (STIA LAN), Jakarta. Penulis juga tercatat sebagai Dosen pada Fakultas Teknologi Informasi, Universitas Budi Luhur. Publikasi ilmiah di jurnal nasional yaitu Akuntabilitas Birokrasi Sebagai Upaya Pengarusutamaan Pencegahan Korupsi di Indonesia.

Nico Andrianto, S.E., M.P.P., Ak., CA adalah Kepala Seksi Evaluasi dan Pelaporan Pemeriksaan Kinerja II pada Direktorat Evaluasi dan Pelaporan Pemeriksaan, Badan Pemeriksa Keuangan Republik Indonesia. Menyelesaikan Master of Public Policy dari Crawford School of Public Policy, The Australian National University, Canberra, Australia, jurusan Policy and Governance. Saat ini sedang menempuh Program Doktor Terapan Ilmu Administrasi Pembangunan Negara, Sekolah Tinggi Ilmu Administrasi, Lembaga Administrasi Negara (STIA LAN), Jakarta. Publikasi Ilmiah di Jurnal Nasional yaitu Manfaat Pemeriksaan Kinerja terhadap Auditee Badan Pemeriksa Keuangan Republik Indonesia, Matra Pembaruan, Pengembangan Kapasitas Pemeriksaan Kinerja di BPK dan ANAO: sebuah Kajian Perbandingan, dan Analisis Kebijakan Publik dalam Pemeriksaan Kinerja, Jurnal Tata Kelola Dan Akuntabilitas Keuangan Negara. 